\title{
Botanical Note \\ The Rediscovery of Papyrus (Cyperus papyrus L.), on the bank of the Damietta branch of the Nile Delta, Egypt
}

\author{
Mamdouh S. Serag \\ Botany Department, Faculty of Science, Mansoura University, \\ New Damietta, P.O. Box 34517 (54), Egypt \\ E-mail: Serag_1999@yahoo.com
} Serag, M. S. 2000. The Rediscovery of Papyrus (Cyperus papyrus L.), on the bank of the Damietta branch of
the Nile Delta, Egypt. Taeckholmia 20 (2):195-198.

Cyperus papyrus was rediscovered in two stands on the eastern bank of the Damietta branch of the Nile Delta. The first stand is located at Sharabas village ca. $24 \mathrm{~km}$ south of Damietta. The growth of papyrus at this site is rich and giant where the habitat conditions are favorable for swampy vegetation. The second stand is recorded at Dahtora about one kilometer north of Zifta town with a feeble growth of an average height of one meter. Ecological notes and reasons of extinction of this important sedge are briefly discussed.

Key words: Damietta branch, Discovery, Nile Delta, Papyrus.

Papyrus, Cyperus papyrus L. was the symbol of lower ancient Egypt (Sculthorpe, 1967). The importance of this plant to the ancient cultures was demonstrated in the paintings and carvings on ancient Egyptian tombs (Täckholm, 1976; Mitchell, 1986). According to Täckholm \& Drar (1950), papyrus had become almost extinct from Egypt more than 150 years earlier. The last traveller to notice papyrus was Baroness V. Minutoli who recorded it growing naturally at Damietta and the shores of Lake Manzala during 1820-21. The few specimens cultivated in the gardens of Cairo and Alexandria were introduced to Egypt from Paris in 1872. The disappearance of papyrus may be due to extended cultivation and perennial irrigation of the Nile banks, and may be also due to the fact that papyrus is no longer needed for paper manufacturing.

In July 1968, El Hadidi (1971) discovered a stand consisting of about 20 plants of Cyperus papyrus L. growing among other reeds in a swamp close to Umm Risha Lake, the largest soda-lake in Wady Natroun depression. It was believed to be the only known locality in Egypt and eventually in North Africa. El Hadidi (1971, op.cit.), argued that the complete disappearance of papyrus from Egypt might be related to the changes in environmental conditions, which have become unfavourable to its natural growth. On the other hand, the biotic competition may be one of the factors, which led to its extinction. The domination of Phragmites australis (Cav.) Trin Ex. Steud and Typha domingensis Pers., Saccharum spontaneum L. v. aegyptacum (Willd.) Hack. and Vossia cusipdata Griff. may explain the role of these plants to grow and stress papyrus (Migahid, 1947). Similar conclusion was reported by Holm et al. (1977) where Phragmites australis (Cav.) Trin Ex. Steud and Vossia cusipdata Griff. quickly supress Cyperus papyrus L.

Searching for papyrus in the Nile Delta started sometime ago by the author. Field

Received 25 November 2000 . Revision accepted 20 December 2000.

$-195-$ 
excursions were conducted to explore the possibility of its occurrence in the northern parts of the Nile Delta.

The author was most fortunate to discover a wild and rich growth of Cyperus papyrus L. on 14 July 2000 . This stand $\left(\sim 40 \mathrm{~m}^{2}\right.$ in area) is recorded on the bank of the Nile at Shrabas village ca. $24 \mathrm{~km}$. south of Damietta (Figure 1).

The most common species recorded in the stand at Shrabas include: Saccharum spontaneum L. v. aegyptacum (Willd.) Hack., Phragmites australis (Cav.) Trin. Ex. Steud (feeble growth), Echinochloa stagnina (Retz.) Beauv., Persicaria tomentosa Willd. and Eichhornia crassipes (Mart.) Solms (on the border of the stand).

The habitat conditions at Sharabas site were favourable for the flourishing of papyrus. The muddy substratum is easily penetrable, water supply is adequate and stagnant, light is intense, air is humid. Furthermore, nutrients are plentiful and flourishing for papyrus. Field studies indicate that the plant forms a dense mass of clumps. The aerial branches are at different stages of development. Old branches dry out continually and are replaced by new sprouts. The rhizome of papyrus is layered and the uppermost layer is the latest formed, and bears the green culms. The lower rhizome layers bear remnants of dry branches and are at different stages of decay. The rhizome mass is rising to a height of one meter above the level of the substratum. Extensive ecological studies are required to explain why the wild papyrus is confined to this location on the Nile bank.

A second stand with a feeble growth of papyrus was discovered on 30 August, 2000 on the western bank of the Nile at Dahtora about one kilometer north of Zifta town (Figure 1). The most common associated species in the stand at Dahtora are Phragmites australis (Cav.) Trin. ex. Steud, Cyperus articulatus L., Bassia indica Wight, Cynodon dactylon (L.) Pers., and Phyla nodiflora (L.) Greene.

Voucher specimens of papyrus and the associated species are kept in the Herbarium of the Botany Department, Faculty of Science (Damietta), Mansoura University and a duplicate series is kept in Cairo University Herbarium.

An attempt is in progress to grow this highly economic sedge for paper production and to test its role in wastewater treatment. Also, pollen grains investigation is to be carried out (personal communication with Prof. M. N. El Hadidi, Cairo University) which may throw light on the past history of the study area. 


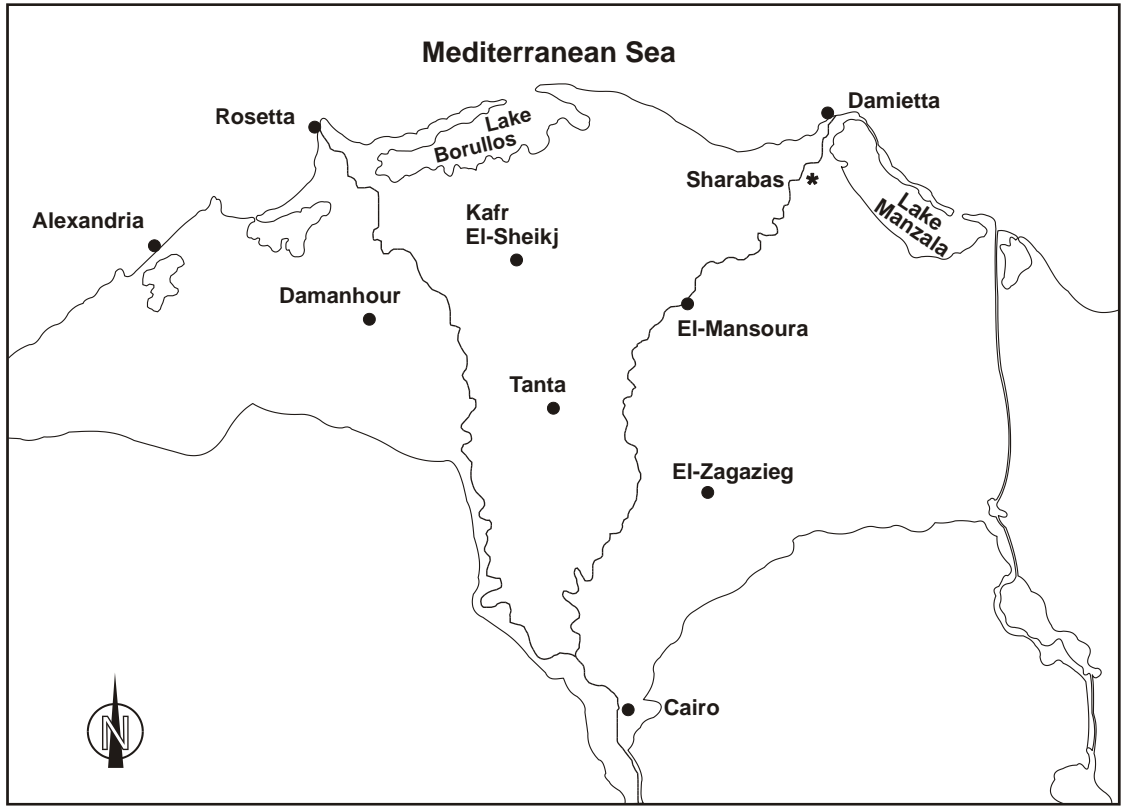

Fig. (1): Location map showing the sites (*) where Papyrus (Cyperus papyrus L.) was rediscovered.

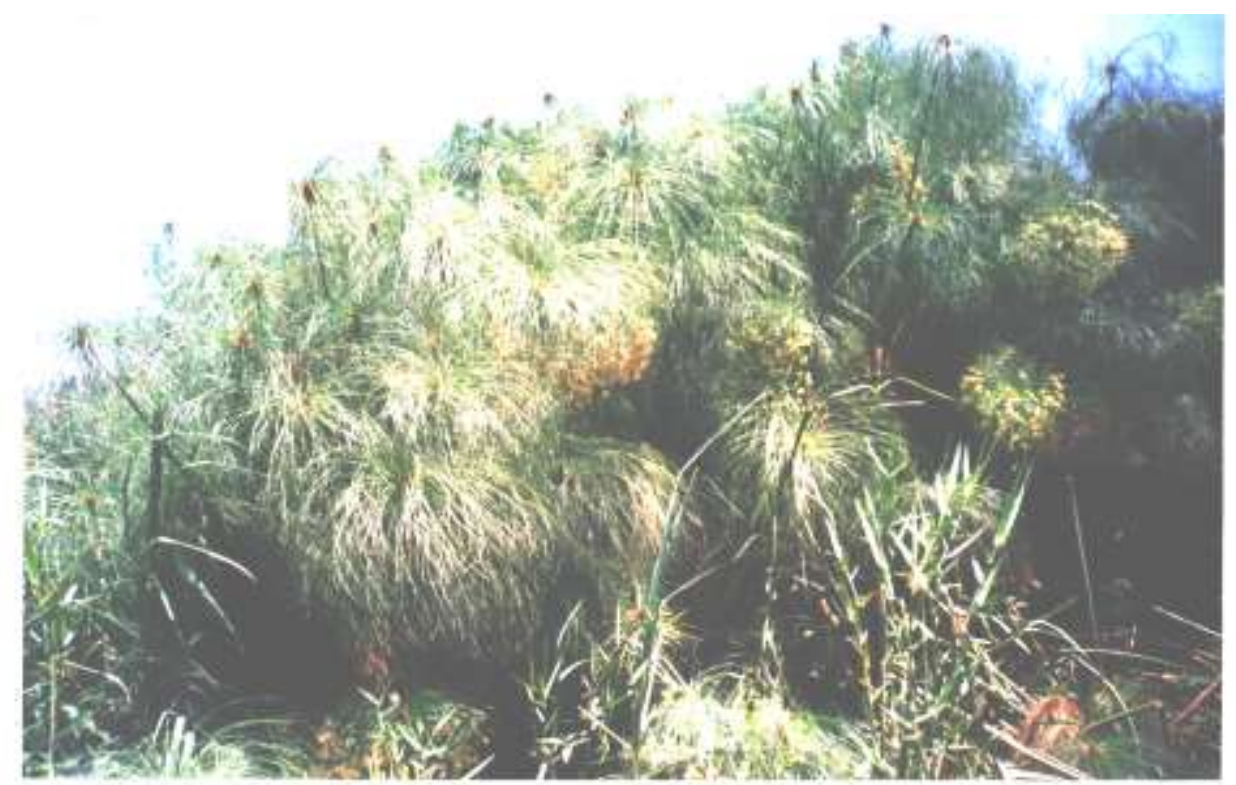

Fig. (2): Vigorous growth of Cyperus papyrus L. growing on the bank of the Nile at Sharabas village (ca. $24 \mathrm{~km}$ south of Damietta). Feeble growth of associated Phragmites also is seen (Photo. By the author on 14/7/2000, the date of rediscovery). 


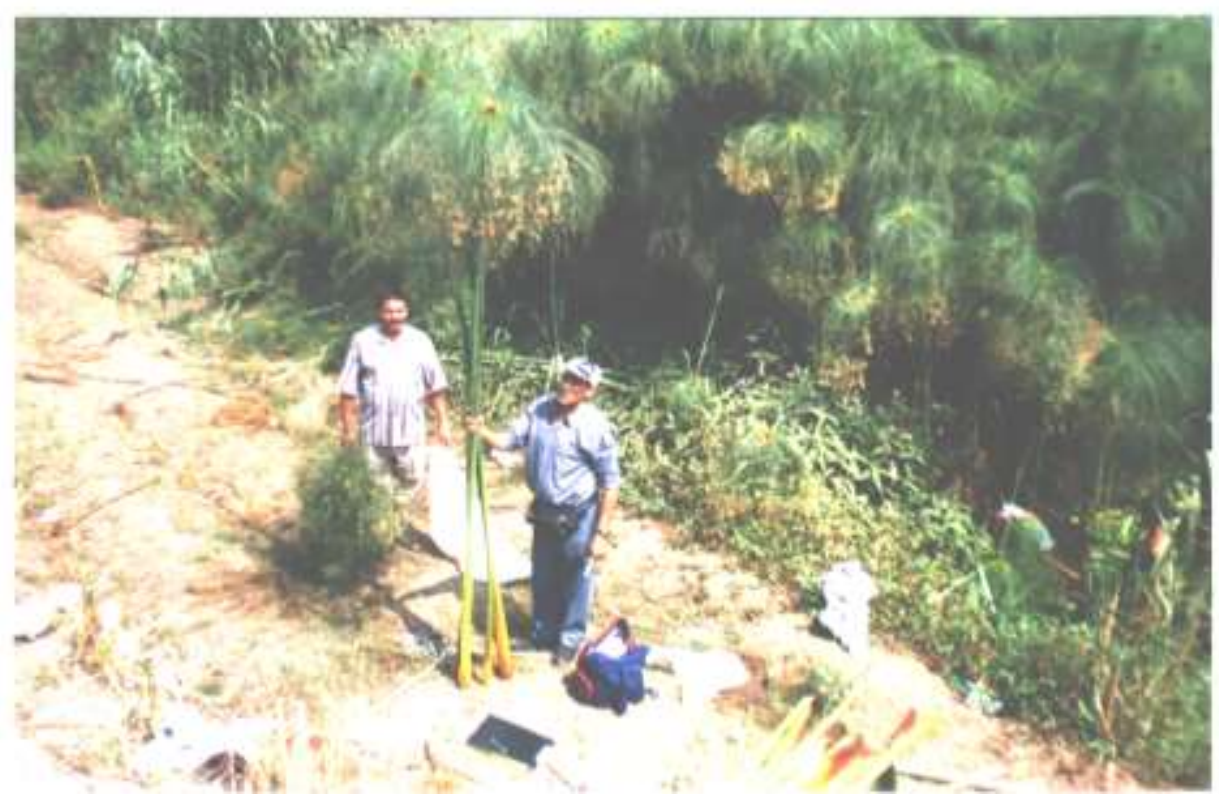

Fig. (3): The author who is on the right side during the sampling of Cyperus papyrus. Note the giant growth of papyrus with an average height $360 \mathrm{~cm}$. Flowering Perscaria tomentosa is growing as an associate with papyrus.

\section{References}

El Hadidi M.N. 1971. Distribution of Cyperus papyrus L. and Nymphaea lotus L. in inland waters of Egypt. Mitt. Bot. Staatssamml. München $10: 470-475$.

Holm L.G, Plucknett D.L., Pancho J.V. \& Herberger J.P. 1977. The World's Worst Weeds: Distribution and Biology. University Press of Hawaii, Honolulu, 375-378 pp.

Migahid A. M. 1947. An ecological study of the "Sudd Swamp" of the upper Nile, Reprinted from Proceedings Vol. III. 1947, Published by the Egyptian Academy of Sciences, $41 \mathrm{pp}$.

Mitchell C. P. 1986. Effects of introduced Grass carp on populations of two species of small native fishes in a small lake. New Zealand Journal of Marine and Freshwater Research. 20: 219- 30.

Sculthorpe C. D. 1967. The Biology of Aquatic Vascular Plants' Edward Arnold, London. (Reprinted by Koeltz Scientific Konigstein, W. Germany, 1985)

Täckholm V. 1976. Ancient Egypt, Landscape, Flora and Agriculture, in J. Rzoska (ed) "The Nile", Biology of Ancient River Dr. W. Junk B.V., Publishers, The Hague pp 51- 68.

Täckholm V. \& Drar M. 1950. Flora of Egypt vol. 2. Bull. Fac. Sci., Fouad I Univ. 28:449-482. 